\title{
Facing the ongoing challenge of the febrile young infant
}

Adrienne G. DePorre ${ }^{1,2^{*}}$, Paul L. Aronson ${ }^{3}$ and Russell J. McCulloh ${ }^{1,2}$

Abstract
This article is one of ten reviews selected from the
Annual Update in Intensive Care and Emergency
Medicine 2017. Other selected articles can be found
online at http://ccforum.com/series/annualupdate2017.
Further information about the Annual Update in
Intensive Care and Emergency Medicine is available
from http://www.springer.com/series/8901.

\section{Background}

Fever in young infants (i. e., infants $\leq 90$ days of life) is a frequent complaint encountered by health care providers, and medical decision-making regarding testing, disposition, and treatment of the febrile infant can be challenging. In the developed world, these otherwise well-appearing young infants are commonly evaluated by clinicians in the ambulatory and emergency department (ED) setting, and they pose a significant conundrum to clinicians for a variety of reasons.

Fever is often the only sign of illness in young infants, making it clinically difficult to differentiate infants with a benign self-limiting illness from those with a more serious illness that could progress to sepsis, permanent disability or death if left untreated. Because of this clinical uncertainty, many febrile young infants undergo invasive testing, are administered empiric antibiotics and are admitted to the hospital. Currently there is no consensus regarding the optimal management and treatment strategy for the febrile young infant. While multiple criteria have been developed to stratify infants based on their risk for serious bacterial infections, the most commonlyused of these criteria are over 25 years old, and these criteria do not account for the changing incidence and

\footnotetext{
* Correspondence: adeporre@cmh.edu

${ }^{1}$ Children's Mercy Hospital, Department of Pediatrics, Division of Hospital Medicine, 2401 Gillham Rd, MO 64108 Kansas City, USA

${ }^{2}$ Department of Pediatrics, University of Missouri-Kansas City, MO 64108

Kansas City, USA

Full list of author information is available at the end of the article
}

epidemiology of invasive infections in young infants or for advances in medical technology for identifying bacteria and viruses responsible for severe infections. Finally, current treatment recommendations largely ignore the potential negative consequences of over-testing, including false-positive test results, excessive antibiotic use and the psychological and financial hardships to which patients' families may be subjected in the course of evaluating these at-risk infants.

In this chapter, we will highlight the historical context of febrile infant management, review important definitions and terminology, discuss the most clinically relevant viral and bacterial causes of fever in the young infant, describe current risk stratification tools guiding medical-decision making, and outline research and clinical practice improvement priorities for improving the management of the febrile young infant.

\section{Historical context}

Since the mid-1970s, there have been numerous published recommendations for the suggested work-up and treatment of nontoxic young febrile infants. These recommendations have changed through the years as medical technology, antibiotic agents and maternal and neonatal healthcare have advanced, and as emerging information is shared. Many of the first recommendations were based on prior reports of occult bacteremia in children, which most often were caused by Streptococcus pneumoniae, Hamophilus influenzae type $b$, and Neisseria meningitidis, leading to invasive meningitis $[1,2]$. Early reports focusing on infants in the first 1-3 months of life identified Streptococcus agalactiae (hereafter referred to as Group B Streptococci [GBS]) and enterobacteraceae, especially Escherichia coli and Salmonella spp., as common causes of bacteremia and meningitis [3-5]. Due in part to these risks, in the 1970 s and early 1980 s it was generally recommended that all febrile infants have blood, urine and cerebrospinal fluid (CSF) cultures drawn, receive empiric antibiotics, and be admitted to the hospital pending culture results, though 
the exact age limit for when this strategy should generally be employed varied widely.

In the mid-1980s, reflecting healthcare overutilization and risks associated with previous recommendations, risk-stratification algorithms based on clinical and laboratory features were created that identified infants at lower risk for serious bacterial infection who could safely be monitored outside of the hospital and often without antibiotics [6]. The most commonly used criteria in the US that were developed during this time include the Boston, Milwaukee, Philadelphia, and Rochester criteria. These criteria, developed largely on single-site experiences with evaluating febrile infants at tertiary medical centers, were effective in identifying infants at relatively low risk for bacterial meningitis and bacteremia (negative predictive value [NPV] 93-100\%) [7-10]. These criteria form the basis for many local and professional society recommendations and clinical practice guidelines currently in use by healthcare providers $[6,11]$.

However, while these criteria demonstrate reasonably high reliability for identifying infants at low risk for serious bacterial infection, there are increasing limitations. First, these criteria were not designed to identify febrile young infants at high-risk for bacterial infection. Second, none of the risk-stratification systems reliably identified low-risk infants younger than 1 month of age. Additionally, none of the algorithms could account for subsequent technological advances for rapidly and reliably diagnosing viral infection in young infants, which can greatly affect the likelihood of an infant having a bacterial infection [12]. Given these limitations, it is unsurprising that contemporary practices in evaluating and managing young febrile infants vary widely in both the inpatient and outpatient settings [11, 13].

\section{Definitions}

Fever in young infants is defined as a rectally-obtained temperature $\geq 38{ }^{\circ} \mathrm{C}$ (100.4 F). Temperature taken by touch, in the axilla or the ear is less accurate, although studies have also shown that caregiver reports of fever correlated with rectal thermometer measurement in up to $79 \%$ of patients $[14,15]$. Thus, it is recommended that infants solely with caregiver report of fever be taken as seriously as those with findings of fever at the clinical visit.

Common terms used in discussions focused on febrile young infants that warrant further definition include 'serious bacterial infection' and 'invasive bacterial infection'. The term serious bacterial infection classically includes bacterial urinary tract infection (UTI), bacteremia and bacterial meningitis. Occasionally, in cases where a known bacterial pathogen is identified as the cause, bacterial pneumonia, enteritis, skin and soft tissue infections and bone infections are included under the term serious bacterial infection [16].

More recently, the phrase invasive bacterial infection has been used to describe infants with bacterial meningitis or bacteremia, reflecting the generally good outcomes of infants diagnosed with UTI [17]. Some experts recommend the sole use of infection source (e. g., meningitis, bacteremia, UTI, etc.) to promote clarity in nomenclature.

\section{Epidemiology of infections in febrile infants}

Viruses are thought to cause the majority of febrile illnesses in young infants, and identifying a viral infection is often associated with a lower risk of bacterial infection in these infants (Table 1). A comprehensive description of the exact epidemiology and incidence of bacterial causes of fever in the young infant is difficult. To date, no large-scale, multi-site estimates of bacterial infection prevalence have been conducted, with available reports relying on data obtained primarily from single-site surveys over varying time periods. High-quality data on the prevalence of bacterial infections in different age groups is also lacking [1]. Overall, bacterial infections are identified in roughly $8-10 \%$ of febrile infants.

\section{Viral infections}

Herpes simplex virus (HSV) is a rare but significant cause of morbidity and mortality among febrile infants, being identified in $<0.3 \%$ of febrile infants, but with an associated mortality of $>15 \%$, a risk that is increased with delay in initiation of antiviral therapy $[18,19]$. The majority of neonatal HSV disease is transmitted to the newborn by active maternal shedding of the virus during the peripartum period. Infection most commonly occurs in the first month of life, and it is exceedingly rare in children older than 6-8 weeks of age. HSV infection can be categorized as limited to skin, eye, mouth (SEM disease); disseminated disease/sepsis; or meningoencephalitis (which can complicate both sepsis and SEM disease), and can be caused by either HSV-1 or HSV-2. Fever can be the only feature of HSV infection, although it may be lacking in up to $50 \%$ of infants ultimately diagnosed with HSV disease, and other clinical symptoms, including vesicular rash, seizures, ill or toxic appearance, irritability, lethargy, conjunctivitis, bulging fontanel and temperature instability, can aid in the diagnosis [20]. These clinical symptoms, along with laboratory findings, such as elevated liver function tests and CSF pleocytosis, are more commonly found in infants with HSV than without, and the presence of any of these signs and symptoms should prompt the consideration of HSV testing and empiric treatment with acyclovir.

Enterovirus is one of the most common causes of febrile illness in young infants and its incidence varies seasonally, with rates being highest in the summer and fall. During these times, enterovirus infection is 
Table 1 Common viral illnesses presenting as fever in young infants and association with bacterial illness. Data from references $[21,24,25,45-48]$

\begin{tabular}{|c|c|c|}
\hline Virus & Recommended diagnostic test & Association with bacterial illness \\
\hline Enterovirus (EV) & CSF EV PCR; EV serum PCR if EV sepsis is suspected & $\begin{array}{l}\text { Low risk for concomitant bacterial meningitis and } \\
\text { bacteremia. Decreased risk for UTI }\end{array}$ \\
\hline Human parechovirus (HPeV) & CSF HPeV PCR & $\begin{array}{l}\text { Insufficient data, but likely decreased risk of bacterial } \\
\text { meningitis, bacteremia, and UTI }\end{array}$ \\
\hline Respiratory syncytial virus (RSV) & Nasopharyngeal RSV Ag detection or RSV RT-PCR & $\begin{array}{l}\text { Low risk for concomitant bacterial meningitis or } \\
\text { bacteremia. Decreased risk for UTI }\end{array}$ \\
\hline Influenza A/B & $\begin{array}{l}\text { Nasopharyngeal Influenza A/B Ag detection or } \\
\text { Influenza A/B RT-PCR }\end{array}$ & Low risk for concomitant bacterial infection \\
\hline Human rhinovirus (hRV) & Nasopharyngeal rhinovirus PCR & $\begin{array}{l}\text { Unknown. Due to prolonged viral shedding, unable } \\
\text { to solely attribute febrile illness to rhinovirus }\end{array}$ \\
\hline Adenovirus (ADV) & Nasopharyngeal adenovirus RT-PCR & $\begin{array}{l}\text { Unknown. Due to prolonged viral shedding, unable } \\
\text { to solely attribute febrile illness to adenovirus }\end{array}$ \\
\hline Human parainfluenza virus (HPIV) 1,2,3,4 & Nasopharyngeal HPIV 1,2,3,4 RT-PCR & $\begin{array}{l}\text { Insufficient data, but likely low risk of concomitant } \\
\text { bacterial infection }\end{array}$ \\
\hline Rotavirus (ROTA) & $\begin{array}{l}\text { Stool rotavirus Ag detection, stool rotavirus enzyme } \\
\text { immunoassay or rotavirus PCR }\end{array}$ & $\begin{array}{l}\text { Insufficient data, but likely low risk of concomitant } \\
\text { bacterial infection }\end{array}$ \\
\hline Herpes simplex virus (HSV) Types 1 and 2 & $\begin{array}{l}\text { CSF HSV PCR, viral culture or PCR of vesicles } \\
\text { Surface cultures in neonates (mouth, nasopharynx, } \\
\text { conjunctivae, perianal) } \\
\text { Serum HSV PCR (if available) }\end{array}$ & $\begin{array}{l}\text { Insufficient data, but likely low risk of concomitant } \\
\text { bacterial infection }\end{array}$ \\
\hline Human herpes virus-6 (HHV-6) & $\begin{array}{l}\text { Plasma HHV-6 RT-PCR; HHV-6 serologic antibody } \\
\text { titers }\end{array}$ & $\begin{array}{l}\text { Insufficient data, but likely low risk of concomitant } \\
\text { bacterial infection }\end{array}$ \\
\hline
\end{tabular}

$P C R$ polymerase chain reaction, $R T-P C R$ reverse-transcriptase polymerase chain reaction, CSF cerebrospinal fluid, UTI urinary tract infection

found in $40-50 \%$ of admitted febrile infants [21]. Because enterovirus-positive infants have a low rate of concomitant bacterial infections, management of enterovirus-positive infants often consists of supportive care alone. A rare manifestation of enterovirus infection in neonates includes severe viral sepsis, which is generally associated with maternal acute infection with enterovirus near the time of delivery. Treatment for enterovirus sepsis is also limited to supportive care with the possible addition of intravenous immune globulin, as no FDA-approved or compassionate-use antiviral therapy is currently available. Testing for enterovirus is encouraged, especially during summer and fall seasons, as a confirmed diagnosis allows clinicians to safely decrease hospital length of stay and antibiotic exposure for otherwise well-appearing febrile infants [22].

Human Parechovirus ( $\mathrm{HPeV})$ is a relatively recently described cause of viral meningitis and encephalitis among febrile infants. Similar to enterovirus, $\mathrm{HPeV}$ is a picornavirus with seasonal variation, and treatment consists largely of supportive care. Compared to enterovirus-positive infants, $\mathrm{HPeV}$-positive infants typically appear more acutely ill and more often require ICU care [23]. While the rates of concomitant bacterial infections are thought to be low (similar to those of enterovirus), suggesting that $\mathrm{HPeV}$-infants could be monitored off antibiotics, further data are needed to confirm this [23].
Respiratory viruses, particularly respiratory syncytial virus (RSV), influenza viruses $A$ and $B$, rotavirus, and rhinovirus are also commonly identified in the febrile infant (Table 1). With the exception of rotavirus, these viruses often cause respiratory symptoms, most commonly manifested as bronchiolitis. Because well-appearing febrile RSV-positive infants are at low risk for bacterial meningitis and bacteremia, but still have a notable risk for bacterial UTI [24], management and testing of these infants should include urinalysis and urine culture, and in most well-appearing infants without evidence of UTI, antibiotics and routine lumbar punctures can be safely delayed or avoided. Similarly, the risk of bacterial infection among infants with influenza or rotavirus is low [25]. The detection of rhinovirus in the otherwise well-appearing febrile infant does not necessarily decrease an infant's risk for concomitant bacterial infection because, due to its long shedding period, detection of the virus may not correlate with acute viral illness [26].

Other viruses and their potential association with the risk of bacterial infection in febrile young infants are detailed in Table 1.

\section{Bacterial infections}

A description of the exact epidemiology and incidence of bacterial causes of fever in the young infant is difficult, as recent large datasets are lacking. However, metaanalyses and data from single-center or regional data in 
the United States suggest that while the majority of bacterial infections used to be due to GBS, and Listeria was of relatively greater concern, E. coli and other Gramnegative bacteria now account for the majority of infections, and Listeria monocytogenes is a rarely encountered pathogen [27, 28].

In addition to $E$. coli, other Gram-negative infections of importance include Klebsiella pneumoniae, Citrobacter spp., Enterobacter spp., Salmonella spp. and Serratia marcescens. About $20 \%$ of serious bacterial infections are thought to be due to Gram-positive bacteria [15]. The most commonly-isolated Gram-positive organisms include GBS, Staphylococcus aureus and Enterococcus spp. L. monocytogenes is now considered an extremely rare cause of serious bacterial infection in the United States [27-29].

UTIs are the most common cause of serious bacterial infection, with $E$. coli causing the majority of infections. It is thought that UTIs occur in roughly $9 \%$ of all febrile infants who undergo medical evaluation, making up roughly $85 \%$ of all serious bacterial infection in this population $[16,24]$. Despite the relatively high incidence of UTI among febrile infants, consensus regarding the disposition and treatment duration of febrile young infants with UTI is lacking. The perceived risk of developing concomitant bacteremia or meningitis and/or long-standing renal injury drives common practice, which frequently includes hospital admission, invasive CSF testing, and often a 2week course of parenteral antibiotics.

It is now questioned whether these infants should be treated less conservatively, as the risk of bacterial meningitis, shock, or death is thought to be extremely low in otherwise well-appearing infants [17]. While the risk of bacteremia secondary to UTI remains substantial, it is unlikely to be associated with adverse effects, and recent studies on well-appearing infants with bacteremia secondary to UTI show similar clinical outcomes between those treated with a prolonged course of parenteral antibiotics vs. those treated with shorter courses of parenteral antibiotics [17, 30, 31].

Bacteremia and bacterial meningitis in febrile infants are thought to occur at an incidence of roughly $1.8-2 \%$ and $0.5-0.7 \%$, respectively $[13,24]$. Unlike UTI, bacterial meningitis is associated with a $5 \%$ mortality risk and long-term sequelae, such as hearing loss, seizures, motor problems, hydrocephalus, and cognitive and behavioral problems, underscoring the need for early detection and treatment of bacteremia (which may lead to bacterial meningitis) and bacterial meningitis [32].

\section{Tools for risk stratification}

A combination of age, clinical appearance and laboratory values is commonly used to identify young febrile infants at risk for a serious bacterial or viral infection.

The Rochester, Philadelphia, Milwaukee and Boston criteria all use the above combination to identify infants at low risk for serious bacterial infection. While the laboratory tests used, interpretation of test results, empirical antibiotic use, and age at which criteria should be applied, vary across these tools, there are many similarities among them (Table 2). Regardless of laboratory values, febrile infants who are ill-appearing or $<28$ days old are identified as at higher risk for serious bacterial infection. It is generally recommended that young febrile infants be evaluated with a complete blood count with differential, urinalysis, blood, and urine culture. Blood and urine tests are often

Table 2 Clinical and laboratory findings of common low-risk criteria. Adapted from [12]

\begin{tabular}{|c|c|c|c|c|}
\hline & Boston & Milwaukee & Philadelphia & Rochester \\
\hline Age range & 28-89 days & $28-56$ days & 29-60 days & $\leq 60$ days \\
\hline History & $\begin{array}{l}\text { No immunizations or } \\
\text { antimicrobials in prior } \\
48 \mathrm{~h}\end{array}$ & Not defined & Not defined & $\begin{array}{l}\text { Term infant; no prior antibiotics; no } \\
\text { underlying disease; no } \\
\text { hospitalization longer than mother }\end{array}$ \\
\hline Physical exam & $\begin{array}{l}\text { Well appearing; no } \\
\text { signs of focal infection }\end{array}$ & $\begin{array}{l}\text { Well appearing; no signs of focal } \\
\text { infection }\end{array}$ & $\begin{array}{l}\text { Well appearing; no signs } \\
\text { of focal infection }\end{array}$ & $\begin{array}{l}\text { Well appearing; no signs of focal } \\
\text { infection }\end{array}$ \\
\hline $\begin{array}{l}\text { Laboratory } \\
\text { parameters }\end{array}$ & $\begin{array}{l}\mathrm{CSF}<10 \mathrm{WBC} / \mathrm{mm}^{3} \\
\mathrm{WBC}<20,000 \mathrm{~mm}^{3} \\
\text { UA }<10 \mathrm{WBC} / \mathrm{hpf} \\
\text { CXR without infiltrate } \\
\text { (if obtained) }\end{array}$ & $\begin{array}{l}\mathrm{CSF}<10 / \mathrm{mm}^{3} \\
\mathrm{WBC}<15,000 / \mathrm{mm}^{3} \\
\text { UA }<5-10 \mathrm{WBC} / \mathrm{hpf}^{\mathrm{U}} \mathrm{UA} \text { no bacteria, } \\
\text { negative leukocyte esterase, negative } \\
\text { nitrites } \\
\text { CXR without infiltrate }\end{array}$ & $\begin{array}{l}\mathrm{CSF}<8 \mathrm{WBC} / \mathrm{mm}^{3} \\
\mathrm{WBC}<15,000 / \mathrm{mm}^{3} \\
\text { UA }<10 \mathrm{WBC} / \mathrm{hpf} \\
\text { CXR without infiltrate } \\
\text { (if obtained) }\end{array}$ & $\begin{array}{l}\text { WBC }>5000 \text { and }<15,000 / \mathrm{mm}^{3} \\
A B C<1500 / \mathrm{mm}^{3} \\
\text { UA } \leq 10 \mathrm{WBC} / \mathrm{hpf} \\
\text { CXR without infiltrate (if obtained) } \\
\text { Stool: WBC } \leq 5 / \mathrm{hpf} \text { smear } \\
\text { (if indicated) }\end{array}$ \\
\hline $\begin{array}{l}\text { Management } \\
\text { strategies for } \\
\text { high risk }\end{array}$ & $\begin{array}{l}\text { Hospitalize, empiric } \\
\text { antibiotics }\end{array}$ & Not defined & $\begin{array}{l}\text { Hospitalize, empiric } \\
\text { antibiotics }\end{array}$ & Hospitalize, empiric antibiotics \\
\hline $\begin{array}{l}\text { Management } \\
\text { strategy for low } \\
\text { risk }\end{array}$ & $\begin{array}{l}\text { Home/outpatient ok } \\
\text { Empiric antibiotics, } \\
\text { outpatient follow up } \\
\text { required }\end{array}$ & $\begin{array}{l}\text { Home/outpatient ok } \\
\text { i.m. ceftriaxone } 50 \mathrm{mg} / \mathrm{kg} \text { followed by } \\
\text { outpatient follow up within } 24 \mathrm{~h} \\
\text { Must have reliable caretaker }\end{array}$ & $\begin{array}{l}\text { Home/outpatient ok } \\
\text { No antibiotics, but } \\
\text { outpatient follow up is } \\
\text { required }\end{array}$ & $\begin{array}{l}\text { Home/outpatient ok } \\
\text { No antibiotics, but outpatient follow } \\
\text { up is required }\end{array}$ \\
\hline
\end{tabular}


obtained simultaneously, and obtaining CSF depends on which strategy is used. Chest radiographs are not routinely recommended.

Although useful in predicting illness severity in older infants and children, the Yale Observational Score, a scoring system that uses clinical signs and symptoms to determine the risk of serious bacterial or viral illness, is not an accurate risk-stratification tool among young febrile infants $<8$ weeks of age [33].

A sequential approach for identifying febrile young infants at low risk for invasive bacterial infection has been proposed. Highlighting UTI as the most common bacterial infection in young febrile infants, this approach recommends evaluating age, clinical appearance and urinalysis results prior to obtaining blood samples [34]. This stepby-step approach has been prospectively validated and has a high sensitivity (92\%) and NPV (99.3\%) [35].

There has been much debate about the utility of certain biomechanical markers as part of a febrile infant evaluation. While an abnormal white blood cell (WBC) count in a febrile young infant is associated with serious bacterial infection, it is not a specific marker for serious bacterial infection (positive predictive value of $30-43.8 \%$ for $\mathrm{WBC}<5,000$ or $>15,000 / \mathrm{mm}^{3}$ ) [12].

Compared to an abnormal WBC, elevated C-reactive protein (CRP) and procalcitonin (PCT) values are associated with serious bacterial infection with a greater sensitivity and specificity, with PCT being more sensitive than CRP for diagnosis of invasive bacterial infection $[34,36]$. CRP can often be elevated in viral infections and does not rise as acutely as PCT levels do, which can cause both false positive and negative results, respectively. While PCT use has been widely investigated in the adult sepsis literature, its use in febrile young infants has been mostly limited to European studies. Using PCT is limited in many non-European countries, as it is not widely available, is not rapidly performed and is associated with high laboratory costs [34, 36]. Combining PCT, CRP and presence of leukocyte esterase or nitrites on urinalysis into a single "lab score" has better specificity to predict the presence of serious bacterial infection than do WBC, CRP or PCT alone, but has a low sensitivity [37]. New research has also identified that an infant produces a unique host response, called an RNA-biosignature, secondary to bacterial infection, which can be detected by microarray analysis. Data on the role of RNA-biosignatures in the management of the febrile young infant are emerging and future studies are needed to evaluate their utility in the clinical setting [38].

Emerging evidence on 1) the changing epidemiology and incidence of bacterial infections; 2) patient outcomes with certain bacterial infections, such as UTIs; 3) the low risk of concomitant bacterial infections among infants with viral illnesses; 4) risk of serious illness with viral illnesses such as enterovirus and HSV; and 5) the need for judicious testing that limits the negative consequences of febrile infant evaluations is reshaping how infants are risk-stratified.

Many health care centers and institutions have created site-specific practice guidelines for the management of the febrile young infant, some of which advocate for more judicious testing and risk-stratify febrile infants based on viral status. These guidelines have been associated with good outcomes, including decreased hospital costs, hospital lengths of stay, and antibiotic exposure without any increase in adverse events [39]. However, guidelines vary widely across institutions, and not all guidelines advocate for more judicious testing and antibiotic use, which can affect health care costs and contributes to the observed variation in practice [11].

\section{Therapeutic options}

For those infants at low risk of serious infection, outpatient management with close monitoring and primary care follow-up is recommended. Antibiotic administration is dependent on which strategy is used, but, in general, antimicrobials should not be given to wellappearing febrile infants until after blood, urine and CSF cultures are obtained.

High-risk infants require hospitalization for empiric intravenous antimicrobials pending bacterial and viral testing results. Hospital length of stay depends on culture and viral testing results. While many clinicians observe infants on empiric antibiotics until all bacterial cultures are negative for $36-48 \mathrm{~h}$, this practice varies widely and is rapidly changing. New evidence has suggested that, due to advances in automated culture detection, an observation period pending negative bacterial culture results at $24-36 \mathrm{~h}$ is often appropriate and can reduce antibiotic exposure, hospital length of stay, and healthcare costs without an increase in missed bacterial infections [39, 40]. In addition, due to the low risk of concomitant bacterial infections, in otherwise wellappearing enterovirus-positive infants, short observation periods of no more than $24 \mathrm{~h}$ are generally recommended [39]. Other potential adjustments to management based on virological test results and PCT results are detailed in Table 3. Hospital admission can often come at a time when infant-family bonding is just beginning, and therefore should focus on maximizing family bonding by encouraging breast feeding, skin-to-skin contact, and maintaining previous routines, while minimizing unnecessary tests and interventions.

Empiric antibiotic choices should cross the blood brain barrier and target the most common pathogens, such as E. coli and GBS. In a large regional study, almost $80 \%$ of infants with meningitis were infected with ampicillin-resistant organisms, highlighting the need for identification of and treatment according to 
Table 3 Diagnostic tests and their utility in the well-appearing febrile young infant. Data from references [22, 25, 49, 50]

\begin{tabular}{|c|c|c|}
\hline Test & Indications & Potential role in management \\
\hline RSV testing & Infants with respiratory symptoms & $\begin{array}{l}\text { If positive, may safely avoid LPs, antibiotic } \\
\text { exposure, and hospitalizations }\end{array}$ \\
\hline EV testing & Infants undergoing LP and CSF studies & $\begin{array}{l}\text { If positive, may consider discontinuing antibiotics, } \\
\text { discharge home if bacterial cultures negative at } \\
24-36 \mathrm{~h}\end{array}$ \\
\hline Influenza testing & $\begin{array}{l}\text { Infants with respiratory symptoms, especially } \\
\text { during high regional prevalence }\end{array}$ & $\begin{array}{l}\text { If positive, may consider discontinuing antibiotics, } \\
\text { discharge home if bacterial cultures negative at } \\
24-36 \mathrm{~h}\end{array}$ \\
\hline Procalcitonin & $\begin{array}{l}\text { Otherwise low-risk infants with negative } \\
\text { virological testing }\end{array}$ & $\begin{array}{l}\text { If normal/minimal elevation: may consider initial } \\
\text { inpatient observation off antibiotics, avoidance of } \\
L P \text {, or outpatient management }\end{array}$ \\
\hline
\end{tabular}

LP lumbar puncture, CSF cerebrospinal fluid, $R S V$ respiratory syncytial virus, $E V$ enterovirus

regional and institution-specific antibiotic resistance patterns [16]. Medication side-effects are also a factor when determining appropriate antibiotic choices. For example, in infants $<28$ days old who are already at increased risk for kernicterus, ceftriaxone is generally avoided as it can cause further increases in serum bilirubin levels.

Commonly-used antibiotic regimens for infants $<28$ days old include ampicillin and either an aminoglycoside, such as gentamicin, or a third-generation cephalosporin, such as cefotaxime. For infants $>28$ days of age, a third-generation cephalosporin, such as ceftriaxone, is often used as monotherapy. For those infants at risk of HSV infection, acyclovir should be empirically administered pending HSV test results.

\section{Unintended consequences of testing/treatment}

The risk of delayed care of a febrile young infant with a serious infection drives invasive testing, hospitalization and antibiotic use, but in some cases these interventions are unnecessary and can often have unintended negative consequences, such as vulnerable child syndrome, family stress, prolonged hospital stay, increased hospital costs, and iatrogenic complications.

Vulnerable child syndrome is a well-described syndrome in which a caregiver's perception of their child as being vulnerable leads to a dysfunctional parent-child relationship. Clinical features of vulnerable child syndrome in the caregiver include excessive separation anxiety, over-protective behavior, difficulties with discipline, and excessive use of the medical system; children can display impaired sleeping habits, difficulties in school, exaggerated separation anxiety, and hypochondria [41, 42]. Children hospitalized early in life, such as those born premature, those with congenital malformations, or those with a suspected serious illness (which one could argue includes suspected meningitis) have been shown to be more prone to vulnerable child syndrome [42].

Parents of hospitalized infants who were interviewed in an effort to better characterize the stress and difficulties families of febrile infants face have previously described believing that their infant had a weak immune system and could rapidly deteriorate or die. Parents have also reported feeling an overwhelming sense of responsibility, a lack of control, experiencing disruption of breast-feeding and increased financial stress [43].

Potentially unnecessary or avoidable testing of febrile infants can cause negative consequences by prolonging hospitalizations and increasing healthcare-related costs. Due to the development of a reliable rapid HSV polymerase chain reaction (PCR) test, many infants at low risk of HSV infection (i. e., well-appearing infants without any historical risks, signs, or symptoms of HSV) are tested and given empiric acyclovir pending PCR results. This testing and empiric treatment of all febrile infants may increase hospital length of stay, and healthcare costs without conferring any additional benefits [44].

Iatrogenic harm caused by the management and treatment of febrile infants has not been well studied. Common sources of iatrogenic harm likely include antimicrobial pretreated CSF cultures and traumatic lumbar punctures [45], which may cause unnecessary antibiotic exposure; radiation exposure from x-rays or other imaging; and phlebitis or venous injury during blood draws or infusions. Due to the relatively low incidence of bacterial infections among febrile infants, bacterial cultures have a low positive predictive value, and can often result in false-positive culture results. False-positive test results likely lead to even further caregiver stress, invasive testing, antibiotic exposure, hospital days and healthcare costs.

\section{Conclusion/future priorities}

Caring for the febrile young infant is often challenging, as the fear of not properly treating a serious illness can often lead to unnecessary testing, antibiotics and hospitalization. To better guide management descisions, future research priorities should focus on using large multi-regional data to identify the incidence and epidemiology of bacterial infections, and further attempts should be made to identify infants at high-risk of 
invasive bacterial and HSV infection. Viral testing should be incorporated into febrile infant evaluations, as identification of a virus may decrease antibiotic exposure, invasive testing and hospitalization. Continued efforts should be made towards the study of novel diagnostic tools such as RNA biosignatures. Finally, there is a large gap in our understanding of the consquences of current febrile infant managment methods, and future efforts should focus on better delineating the risks and unintended consequences of testing, antibiotic administration and hospilization of young febrile infants.

\section{Acknowledgements}

Not applicable.

\section{Funding}

Publication charges will be paid from the Children's Mercy Kansas City Department of Pediatrics through internal funds provided to Dr. McCulloh.

\section{Availability of data and materials}

Not applicable; all data listed was obtained from the references cited within the manuscript.

\section{Authors' contributions}

AD reviewed the relevant literature, wrote, edited, and supervised the editing of the manuscript, and supervised the relevant data synthesis, analysis, and presentation and submitted. PA and RM participated in the review of the relevant literature, assisted in data synthesis, contributed to the drafting and revision of the manuscript, reviewed and approved the final version of the manuscript. All authors read and approved the final manuscript.

\section{Competing interests}

The authors declare that they have no competing interests.

\section{Consent for publication}

Not applicable.

\section{Ethics approval and consent to participate}

Not applicable.

\section{Author details}

'Children's Mercy Hospital, Department of Pediatrics, Division of Hospital Medicine, 2401 Gillham Rd, MO 64108 Kansas City, USA. ²Department of Pediatrics, University of Missouri-Kansas City, MO 64108 Kansas City, USA. ${ }^{3}$ Department of Pediatrics, Section of Pediatric Emergency Medicine, Yale School of Medicine, 100 York St, Suite 1F, New Haven, CT 06511, USA.

\section{Published online: 21 March 2017}

\section{References}

1. Teele DW, Pelton SI, Grant MJA, et al. Bacteremia in febrile children under 2 years of age: Results of cultures of 600 consecutive febrile children seen in a walk-in clinic. J Pediatr. 1975;87:227-30.

2. Long SS. Approach to the febrile patient with no obvious focus of infection. Pediatr Rev. 1984;5:305-15.

3. Crain EF, Shelov SP. Febrile infants: Predictors of bacteremia. J Pediatr. 1982;101:686-9.

4. Crain EF, Gershel JC. Which febrile infants younger than two weeks of age are likely to have sepsis? A pilot study. Infect Dis J. 1988;7:561-4.

5. Roberts KB, Borzy MS. Fever in the first eight weeks of life. Johns Hopkins Med J. 1977:141:9-13.

6. Baraff $\sqcup$. Management of fever without source in infants and children. Ann Emerg Med. 2000;36:602-14.

7. Baker DM, Bell LM, Avner JR. Outpatient management without antibiotics of fever in selected infants. N Engl J Med. 1993:329:1437-41.

8. Bonadio WA, Hagen E, Rucka J, Shallow K, Stommel P, Smith D. Efficacy of a protocol to distinguish risk of serious bacterial infection in the outpatient evaluation of febrile young infants. Clin Pediatr. 1993;32:401-4.
9. McCarthy PL, Sharpe MR, Spiesel SZ, et al. Observation scales to identify serious illness in febrile children. Pediatrics. 1982;70:802-9.

10. Dagan R, Powell KR, Hall CB, Menegus MA. Identification of infants unlikely to have serious bacterial infection although hospitalized for suspected sepsis. J Pediatr. 1985;107:855-60.

11. Aronson PL, Thurm C, Williams DJ, et al. Association of clinical practice guidelines with emergency department management of febrile infants $\leq 56$ days of age. J Hosp Med. 2015;10:358-65.

12. Hui C, Neto G, Tsertsvadze A, et al. Diagnosis and Management of Febrile Infants (0-3 Months). Evidence Report/Technology Assessments, No. 205. AHRQ Publication No. 12-E004-EF. 2012. http://www.ahrq.gov/research/findings/ evidence-based-reports/er205-abstract.html\#Report. Accessed 20 Nov 2016.

13. Pantell RH, Newman TB, Bernzweig J, et al. Management and outcomes of care of fever in early infancy. JAMA. 2004;291:1203-12.

14. Callanan D. Detecting fever in young infants: reliability of perceived, pacifier, and temporal artery temperatures in infants younger than 3 months of age. Pediatr Emerg Care. 2003;19:240-3.

15. Hooker EA, Smith SW, Miles T, King L. Subjective assessment of fever by parents: comparison with measurement by noncontact tympanic thermometer and calibrated rectal glass mercury thermometer. Ann Emerg Med. 1996:28:313-7.

16. Byington $\mathrm{CL}$, Rittichier $\mathrm{KK}$, Bassett $\mathrm{KE}$, et al. Serious bacterial infections in febrile infants younger than 90 days of age: the importance of ampicillinresistant pathogens. Pediatrics. 2003;111:964-8.

17. Schnadower D, Kuppermann N, Macias CG, et al. Febrile infants with urinary tract infections at very low risk for adverse events and bacteremia. Pediatrics. 2010;126:1074-83.

18. Caviness AC, Demmler GJ, Almendarez Y, Selwyn BJ. The prevalence of neonatal herpes simplex virus infection compared with serious bacterial illness in hospitalized neonates. J Pediatr. 2008:153:164-9.

19. Shah SS, Aronson PL, Mohamad Z, Lorch SA. Delayed acyclovir therapy and death among neonates with herpes simplex virus infection. Pediatrics. 2011;128:1153-60.

20. Kimberlin DW. Neonatal herpes simplex infection. Clin Microbiol Rev. 2004:17:1-13.

21. Rittichier KR, Bryan PA, Bassett KE, et al. Diagnosis and outcomes of enterovirus infections in young infants. Pediatr Infect Dis J. 2005:24:546-50.

22. King RL, Lorch SA, Cohen DM, Hodinka RL, Cohn KA, Shah SS. Routine cerebrospinal fluid enterovirus polymerase chain reaction testing reduces hospitalization and antibiotic use for infants 90 days of age or younger. Pediatrics. 2007:120:489-96.

23. Sharp J, Harrison CJ, Puckett K, et al. Characteristics of young infants in whom human parechovirus, enterovirus or neither were detected in cerebrospinal fluid during sepsis evaluations. Pediatr Infect Dis J. 2013;32:213-6.

24. Levine DA, Platt SL, Dayan PS, et al. Risk of serious bacterial infection in young febrile infants with respiratory syncytial virus infections. Pediatrics. 2004;113:1728-34

25. Bender JM, Ampofo K, Gesteland $\mathrm{P}$, et al. Influenza virus infection in infants less than three months of age. Pediatr Infect Dis J. 2010;29:6-9.

26. Loeffelholz MJ, Trujillo R, Pyles RB, et al. Duration of rhinovirus shedding in the upper respiratory tract in the first year of life. Pediatrics. 2014;134:1144-50.

27. Biondi EA, Evans R, Mischler R, et al. Epidemiology of bacteremia in febrile infants in the United States. Pediatrics. 2013;132:990-6.

28. Leazer R, Perkins AM, Shomaker K, Fine B. A meta-analysis of the rates of Listeria monocytogenes and Enterococcus in febrile infants. Hosp Pediatr. 2016:6(4):187-95.

29. Greenhow TL, Hung YY, Herz A, Losada E, Pantell RH. The changing epidemiology of serious bacterial infections in young infants. Pediatr Infect Dis J. 2014;33:595-9.

30. Schroeder AR, Shen MW, Biondi EA, et al. Bacteraemic urinary tract infection: management and outcomes in young infants. Arch Dis Child. 2016;101:125-30.

31. Roman HK, Chang PW, Schroeder AR. Diagnosis and management of bacteremic urinary tract infection in infants. Hosp Pediatr. 2015:5:1-8.

32. de Jonge RC, van Furth AM, Wassenaar M, Gemke RJ, Terwee CB. Predicting sequelae and death after bacterial meningitis in childhood: a systematic review of prognostic studies. BMC Infect Dis. 2010;10:232

33. Baker MD, Avner JR, Bell LM. Failure of infant observation scales in detecting serious illness in febrile, 4- to 8-week-old infants. Pediatrics. 1990:85:1040-3.

34. Mintegi S, Bressan S, Gomez B, et al. Accuracy of a sequential approach to identify young febrile infants at low risk for invasive bacterial infection. Emerg Med J. 2014;31:e19-24. 
35. Gomez B, Mintegi S, Bressan S, et al. Validation of the step-by-step approach in the management of young febrile infants. Pediatrics. 2016; 138, e20154381.

36. Jhaveri R, Byington CL, Klein JO, Shapiro ED. Management of the non-toxicappearing acutely febrile child: a 21st century approach. J Pediatr. 2011;159:181-5.

37. Bressan S, Gomez B, Minteg S, et al. Diagnostic performance of the labscore in predicting severe and invasive bacterial infections in well-appearing young febrile infants. Pediatr Infect Dis J. 2012;31:1239-44.

38. Mahajan P, Kuppermann N, Mejias A, et al. Association of RNA biosignatures with bacterial infections in febrile infants aged 60 days or younger. JAMA. 2016:316:846-57.

39. Byington CL, Reynolds CC, Korgenski K, et al. Costs and infant outcomes after implementation of a care process model for febrile infants. Pediatrics. 2012;130:e16-24.

40. Vamsi SR, Bhat RY, Lewis LE, Vandana KE. Time to positivity of blood cultures in neonates. Pediatr Infect Dis J. 2014;33:212-4.

41. Kokotos F. The vulnerable child syndrome. Pediatr Rev. 2009;30:193-4

42. Rautaya P, Lehtonen L, Helenius $H$, Sillanpää M. Effect of newborn hospitalization on family and child behavior a 12-year follow-up study. Pediatrics. 2003;111:277-83.

43. De S, Tong A, Isaacs D, Craig JC. Parental perspectives on evaluation and management of fever in young infants: an interview study. Arch Dis Child. 2014;99:717-23.

44. Shah SS, Volk J, Mohamad Z, Hodinka RL, Zorc JJ. Herpes simplex virus testing and hospital length of stay in neonates and young infants. J Pediatr. 2010;156:738-43.

45. Pingree EW, Kimia AA, Nigrovic LE. The effect of traumatic lumbar puncture on hospitalization rate for febrile infants 28 to 60 days of age. Acad Emerg Med. 2015;22:240-3.

46. Byington $\mathrm{CL}$, Enriquez $\mathrm{FR}$, Hoff $\mathrm{C}$, et al. Serious bacterial infections in febrile infants 1 to 90 days old with and without viral infections. Pediatrics. 2004;113:1662-6.

47. Mintegi S, Garcia-Garcia JJ, Benito J, et al. Rapid influenza test in young febrile infants for the identification of low-risk patients. Pediatr Infect Dis J. 2009;28:1026-8.

48. Messacar K, Breazeale G, Wei Q, Robinson CC, Dominguez SR. Epidemiology and clinical characteristics of infants with human parechovirus or human herpes virus-6 detected in cerebrospinal fluid tested for enterovirus or herpes simplex virus. J Med Virol. 2015;87:829-35.

49. Byington $\mathrm{CL}$, Castillo H, Gerber K, et al. The effect of rapid respiratory viral diagnostic testing on antibiotic use in a children's hospital. Arch Pediatr Adolesc Med. 2002;156:1230-4.

50. Milcent K, Faesch S, Gras-Le Guen C, et al. Use of procalcitonin assays to predict serious bacterial infection in young febrile infants. JAMA Pediatr. 2016;170:62-9 